\title{
EFFECT OF DIFFERNT SOIL TEXTURAL GRADES AND SOAKER WATER OF ORGANIC MANURE ON VEGETATIVE GROWTH, FLOWERING AND CHEMICAL CONSTITUENTS OF MARIGOLD (TAGETES PATULA L.,) PLANTS.
}

\author{
Sawsan, A. Saif El-Yazal ${ }^{1}$ and Essam G. Somida ${ }^{2}$ \\ 1- Soil and water Dep., Fac. of Agric., Fayoum Univ., Egypt \\ 2- Dep. of Hort., Ministry of Education, Fayoum, Egypt.
}

\section{ABSTRACT}

A pot experiment was carried out during two successive seasons of 2006 and 2007 on marigold "Tagetes patula L." plants to study the effects of different texture grades such as sandy, clay, sandy loam, sandy clay loam and clay loam and organic soaker water of poultry manure at the rates of $0.5,1.0,1.5 \mathrm{~kg}$ soaking, which diluted in 20 liter water for 24 hour and then gave to pot at the rate of $0.5 \mathrm{~L}$. four times per 15 days, on vegetative growth, flowers yield and chemical constituents of marigold "Tagetes patula L." plants. The obtained results indicated that, all plant parameters i.e., plant height, number of branches/plant, herb fresh and dry weight/plant, root fresh and dry weight/plant, number flower, flower fresh and dry weight/plant, flowering\%, volatile $\%$ and yield/plant, caroteniods of flower, $\mathrm{N}, \mathrm{P}$ and $\mathrm{K} \%$ and total carbohydrates $\%$ in the herb were more affected by soil texture grades and poultry manure soaker water rates. Sandy soil gave the lowest values of plant characters and chemical constituents than other studied soil textural grades, but it surpassed the clay soil in root fresh and its dry weight/plant as well as flowering \%. On the other hand clay loam soil gave the greatest values of previous plant characters and chemical constituents than other soil types. The organic soaker fertilizer at the rate of $1.5 \mathrm{~kg} / 20 \mathrm{~L}$. surpassed the other ones of 0.5 and $1 \mathrm{~kg} / 20 \mathrm{~L}$. for producing significantly increased in growth parameters, flowers yield and chemical constituents. Both sandy loam and clay loam which fertilized with organic soaker water, were statistically equal in producing significant values of vegetative growth, flowers yield and chemical constituents of marigold plants in both seasons. So, the highest values of growth, flowers yield and chemical constituents were obtained when Tagetes patula L., plants were grown either on clay loam or sandy loam soil fertilized with soaker water of poultry manure at the rate of $1.5 \mathrm{~kg} / 20 \mathrm{~L}$.

Key word: Marigold "Tagetes patula L.," plants, texture grades, organic soaker water of poultry manure growth, flowers yield and chemical constituents of plant and flowers.

\section{INTRODUCTION}

Marigold plant (Tagetes patula L.,) is summer annual herbs of Asteraceae (Composite) of several classes are valued for the profuse bloom in summer display of their golden flowers. It is planted in beds and borders and also as cut flowers beside its uses as aromatic, drug and colour containing flowers. The petals of marigold flowers are rich in caroteniods which are used commercially for colouring hen eggs and skin of broiler chickens and in food industries as natural colouring materials. Pigments of marigold petels were

Fayoum J. Agric. Res. \& Dev., Vol.22, No.2, July, 2008 
isolated and identified by several authors (Alam et al. 1968 and Miller 1971). The importance of its essential oil extracts from either green organs or flowers was recorded by Kapelev (1971, 1973 and 1975). Also, Chan et al. (1975) isolated thiophene compounds from root of Tagetes patula L., which has an antibiotic activity. Its intercrop is used for controlling plant parasitic nematodes by (Kumari et al. 1987) and the extract of Tagetes spp. showed high insecticidal activity (Darwish 1992).

For obtaining a high yield and neutral production to faraway from environmental pollution hazard we have to use the mineral fertilizer in a smallest amount, as well as using organic culture or manure. So we have to use a combination between the soil types and the rates of organic soaker water such as poultry manure fertilization on Tagetes patula L., plants.

Many investigations carried out experiments dealing with soil type or organic fertilization and its effect on growth and yield of medicinal and aromatic plant. In this respect, El-Shoura and Hosni (1996) on Sterlitzia reginae plants grown in four growing media containing $3: 1,1: 1,1: 3 \mathrm{sand} / \mathrm{clay}$ to clay on its own. The 1:3 sand/clay produced the greatest number of leaves/plant, longest length of leaf/plant and highest dry matter \%. Meanwhile, 1:1 sand/clay gave the longest of length of both flower stems and flower boats. Clay produced the greatest fresh weight of flowers and highest $\mathrm{N}, \mathrm{P}$ and $\mathrm{K} \%$.

Youssef et al. (1998) on Ocimum basilicum L.; EL-Sallami (2002) on Chorisia speciosa seedling and Moustafa (2004) on Dalbergia sissoo and Parkinsonia aculeate found that the clay soil enhanced the vegetative growth characters, pigments and nitrogen $\%$. Sand soil gave the highest root system of both tree species seedlings.

Mahros (1999) and (2000) on tuberose and Aster novi -belgii L., and Soliman (2005) on Khaya segenalensis seedlings plant demonstrated the medium contained clay + sandy 1:1 improved number of main branches and fresh weights of leaves, root, flowering characters as flower yield and weight, caroteniods and nitrogen $\%$.

Saleh (2000) using peatmoss media for growing Ficus benjamina starlight plants gave the best results for plant height, number branches, number of leaf and fresh and dry weights of plants. Also the mixture of peatmoss + sand + clay produced pronounced values of the highest total N, P and K content.

Somida (2002) on Tagetes minuta L., plants using poultry manure at rates $4,8,12 \mathrm{~m}^{3}$ manures enhanced plant height, number of branches, fresh weight of herb, number of inflorescences, volatile oil \% and yield in the herb per plant, caroteniods, $\mathrm{N}, \mathrm{P}, \mathrm{K}$ and total carbohydrate.

Abdou et al. (2003) tested the response of Acacia saligna and five wood tree species to four soil type i.e. sand and sand + clay at rates 1:1, 3:1 and 7:1 respectively and concluded that all studied vegetative growth traits i.e, plant height, stem diameter, fresh and dry weight of each leaves and roots/ plant were significantly improved for each one of the woody tree species due to incorporating sandy soil with clay soil at ratios 7:1, 3:1 and 1:1 over sandy soil.

El-Yazal et al. (2005) and Matter and Somida (2006) recorded that poultry manure fertilizers produced the best results from plant height, number of branches, fresh weight of herb, number of inflorescences, volatile oil percentage, and yield in the herb per plant and per feddan, $\mathrm{N}, \mathrm{P}$ and $\mathrm{K}$ total carbohydrate of the treated sweet basil plants.

Fayoum J. Agric. Res. \& Dev., Vol.22, No.2, July, 2008 
EFFECT OF DIFFERNT SOIL TEXTURAL GRADES AND SOAKER .... 62

Mohamed (2006) found that, the high rate of $30 \mathrm{~m}^{3} /$ fed of poultry manure was more effective many plant characters, i.e, plant height, number of branches/plant, number of capsules/plant, dry weight of leaves/plant, caroteniods, N, P, K and total carbohydrates.

\section{MATERIAL AND METHODS}

A pot experiment was carried out during the two successive seasons of 2006 and 2007 on a private farm in Sennouris, Fayoum Governorate outlived with marigold (Tagetes patula L.,) plants to study the effect of soil texture grades and organic soaker water of poultry manure on growth and chemical constituents of Tagetes patula L. plant. Tagetes patula L seeds were obtained from the Research Center of Medicinal and Aromatic plants in Giza, Egypt in both studied seasons and were sown in seed beds on $15^{\text {th }}$ February of each seasons. After 45 days uniform seedlings (about $10 \mathrm{~cm}$ in height) were individually transplanted in pots $25 \mathrm{~cm}$ diameter, which filled with $8 \mathrm{~kg}$ soil. The pots were arranged in complete randomized block design with 15 treatments representing five soils types having different texture grades with three rates of organic soaker water and 10 replicates. Data were statistically analyzed according to Gomes and Gomes (1983).

Treatments: - Plants were treated with:

1- A natural soils sample was collected from the local farm and was mixed at rates 1:1, 1:2 and 2:1\% from clay and sand, respectively, in addition used clay and sandy alone to obtain five soil texture grades, i.e, sandy, clay, sandy loam, sandy clay loam and clay loam.

2- Poultry manure "PM" was soaking in water for 24 hours at rates $0.5,1.0,1.5$ $\mathrm{kg} / 20 \mathrm{~L}$. of water which irrigate the pot at quantity of 0.5 liter/pot and added after 15, 30 and 40 days from transplanting .

Some soil physical and chemical properties as well as organic soaker water (OSW)) according to the method described by Black et al. (1965) and Chapman and Paratt,. (1978) are shown in Table (1).

\section{Data recorded of plant parameters:-}

1- Vegetative growth parameters:- Plant height $(\mathrm{cm})$, number of branches/plant, herb fresh and dry weight/plant (gm), root fresh and dry weight/plant (gm), Sample of three rates were taken randomly from each harvest to recorded such growth parameters.

2- Flower parameters:- Number of flower, flowers fresh and dry weight/plant(gm), flowering \% Samples were taken randomly $15^{\text {th }}$ Mayo to $15^{\mathrm{h}}$ August to record such growth parameters .

3- Chemical constituents:-Volatile oil percentage and oil yield were determined in the flowers according to British Pharmacopoeia method (1983) by using Clevenger apparatus for the determination of essential oil.. Caroteniods $\mathrm{mg} / 100 \mathrm{~g} \mathrm{~F}$.W. of flower, nitrogen and phosphorus percentage was determined in the herb according to A.O.A.C. (1995). Potassium was determined by Flame Photometer, Parkin-Elmer model 52 with acetylene burner according to Page et al. (1982) Total carbohydrates (mg/g D.W) were determined colorimetric according to the method described by Michel et al. (1956). Samples were taken before flowering, to determine the NPK and Total carbohydrates.

Fayoum J. Agric. Res. \& Dev., Vol.22, No.2, July, 2008 
Table (1): Some physical and chemical analysis of used soil types and chemical analysis of poultry manure soaker water (OSW).

\begin{tabular}{|c|c|c|c|c|c|c|c|}
\hline \multirow{3}{*}{ Properties } & \multicolumn{5}{|c|}{ Poultry fertilizer } & \multicolumn{2}{|c|}{ Soil Types } \\
\hline & $\begin{array}{c}\text { Sandy } \\
\text { (S) }\end{array}$ & $\begin{array}{l}\text { Clay } \\
\text { ( C) }\end{array}$ & $\begin{array}{c}\mathrm{C}+\mathrm{S} \\
1: 1 \\
\end{array}$ & $\begin{array}{c}\mathrm{C}+\mathrm{S} \\
1: 2\end{array}$ & $\begin{array}{c}\mathrm{C}+\mathrm{S} \\
2: 1 \\
\end{array}$ & $\mathrm{Cl} \%$ & 0.054 \\
\hline & & & & & & $\mathrm{Ca} \%$ & 0.014 \\
\hline Sand & 88.89 & 15.78 & 52.33 & 70.61 & 34.06 & $\mathrm{SO}_{4} \%$ & 0.204 \\
\hline Silt & 3.45 & 28.45 & 15.95 & 9.70 & 28.21 & $\mathrm{HCO}_{3}$ & 0.050 \\
\hline clay & 7.66 & 55.77 & 31.72 & 19.69 & 37.73 & $\mathrm{Na} \%$ & 0.300 \\
\hline Texture grade & Sandy & Clay & $\begin{array}{c}\text { Sand clay } \\
\text { loam }\end{array}$ & $\begin{array}{l}\text { Sandy } \\
\text { Loam }\end{array}$ & Clay loam & $\mathrm{Mg} \%$ & 0.006 \\
\hline pH & 7.21 & 7.61 & 7.41 & 7.31 & 7.51 & $\mathrm{pH}$ & 6.90 \\
\hline Ece $(d \mathrm{~S} / \mathrm{m})$ & 0.78 & 0.85 & 0.81 & 0.80 & 0.83 & Ece $(\mathrm{d} \mathrm{S} / \mathrm{m})$ & 9.30 \\
\hline Total N \% & 0.054 & 0.095 & 0.069 & 0.061 & 0.072 & $\mathrm{~N} \%$ & 0.74 \\
\hline P \% & 0.40 & 0.65 & 0.52 & 0.46 & 0.59 & $\mathrm{P} \%$ & 0.63 \\
\hline K \% & 1.45 & 1.89 & 1.67 & 1.56 & 1.78 & $\mathrm{~K} \%$ & 2.60 \\
\hline $\mathrm{Zn}(\mathrm{mg} / \mathrm{kg})$ & 0.99 & 1.19 & 1.09 & 1.04 & 1.14 & $\mathrm{Zn}(\mathrm{mg} / \mathrm{kg})$ & 13.33 \\
\hline Mn (mg/kg) & 1.12 & 3.55 & 2.33 & 1.23 & 2.44 & $\mathrm{Mn}(\mathrm{mg} / \mathrm{kg})$ & 19.70 \\
\hline $\mathrm{Fe} \quad(\mathrm{mg} / \mathrm{kg})$ & 6.15 & 11.55 & 9.85 & 7.35 & 10.7 & $\mathrm{Fe}(\mathrm{mg} / \mathrm{kg})$ & 23.55 \\
\hline
\end{tabular}

RESULTS AND DISCUSSIONS

A - Vegetative growth characteristics:

1 - Plant height (cm) and number of branches per plant:

Data in Table (2) indicated that the soil texture grades significantly affected the plant height and number of branches/plant as compared to sandy and clay soils. Sandy soil gave the lowest values than other studied soil types. Both sandy and clay soils were statistically equal in producing significant values of plant height and number of branches/plant of marigold plant in the two seasons. While clay loam soil gave the greatest values than other soil types. Also both sandy loam and clay loam were statistically equal in producing significant plant height and number of branches/plant of marigold plants in the two seasons. These results are in agreement with the findings reported by ElShoura and Hosni (1996) on Sterlitzia reginae plants Youssef, et al. (1998) on Ocimum basilicum Mahros (2000) on Aster novi -belgii L plants Saleh (2000) on Ficus benjamina starlight plants and Soliman (2005) on Khaya segenalensis seedlings.

The values of plant height and number of branches/plant significantly increased by increasing organic soaker water from the low up to the highest rate in the two growing seasons 0.5 and 1.0 and $\mathrm{kg} / 20 \mathrm{~L}$ were statistically equal in producing significant plant height and number of branches/plant of marigold plants in the two seasons. The organic soaker fertilizer at a rate of $1.5 \mathrm{~kg} / 20 \mathrm{~L}$. surpassed the rates of 0.5 and 1.0 and $\mathrm{kg} / 20 \mathrm{~L}$., in producing significant values of plant height and number of branches/plant in both seasons (Table 2). These results are in agreement with the findings reported by El-Gendy et al. (2001) and El-Yazal, et al. (2005) on Ocimum basilicum L. and Mohamed (2006) on roselle plants. The interaction between the soil texture grades and organic soaker fertilizer significantly increased the values of plant height and number of branches/plant. Sandy soil which fertilized with organic soaker gave the lowest values of plant height and number of branches/plant. While Clay + sandy at rate $2: 1 \%$ (clay loam) which fertilized with organic soaker gave the

Fayoum J. Agric. Res. \& Dev., Vol.22, No.2, July, 2008 
highest values of plant height and number of branches/plant. No significantly different between the sandy and clay soils, while sandy loam (clay +sandy soil at rate $1: 2 \%$ ) and clay loam (clay + sandy soil at rate $2: 1 \%$ ) which fertilized with organic soaker in producing significant values of plant height and number of branches/plant in the two seasons.

\section{2 - Herb fresh and dry weight/ plant (g.):}

The used soil texture grades significantly affected the herb fresh and dry weight/plant, whether sandy soil gave the lowest values than other soil types. Both sandy and clay soils were statistically equal in producing significant values for herb fresh and dry weight/ plant of marigold plant in the two seasons. Clay loam soil (clay + sandy at rate 2:1\%) gave the highest values than the other soil types which reached $128.72,152.64$ and $176.89 \mathrm{~g}$ in season of 2006 ; 130.94, 155.09 and $179.45 \mathrm{~g}$ in season of 2007 for the organic soaker rates of $0.5,1.0$ and $1.5 \mathrm{~kg} / 20 \mathrm{~L}$., respectively. Both sandy loam and clay loam were statistically equal in producing significant herb fresh and dry weight/ plant of marigold in the two seasons. plants. as indicate the data in Table (2). Similar results were respected by El-Shoura and Hosni (1996) on Sterlitzia reginae plants Youssef et al. (1998) on Ocimum basilicum Mahros (2000) on Aster novi -belgii L., plants Saleh (2000) on Ficus benjamina starlight plants.

The herb fresh and dry weight/ plant significantly increased by increasing organic soaker rates in the two growing seasons. The rate of $1.5 \mathrm{~kg} / 20 \mathrm{~L}$. from poultry manure soaker fertilizer surpassed the rates of 0.5 and 1.0 and $\mathrm{kg} / 20 \mathrm{~L}$. in producing significant herb fresh and dry weight/ plant in the two seasons in Table (2). So the highest values were obtained when marigold plants received soaker water of poultry manure at the rate $1.5 \mathrm{~kg} / 20$ Liter of water. These results are in agreement with the findings reported by ElYazal et al. (2005) on Ocimum basilicum L. Mohamed (2006) on roselle plants.

Data in table (2) show that the difference between the soil types plus organic soaker significantly increased herb fresh and dry weight/plant. Sandy soil which fertilized with organic soaker gave the lowest values of herb fresh and dry weight/ plant. While, clay loam soil, which fertilized with organic soaker gave the highest value of herb fresh and dry weight/ plant. No significantly differences were noticed between the interaction of sandy, clay and sandy clay loam soils and organic soaker. But clay loam which fertilized with organic soaker produced significant herb fresh and dry weight/ plant in the two seasons. So, the highest values were obtained when marigold plants were grown on clay loam and fertilized with poultry manure soaker at a rate of 1.5 $\mathrm{kg} / 20 \mathrm{~L}$. water.

\section{3- Root fresh and dry weight/plant (gm):}

Data in Table (2) indicate that the used soil texture grades significantly affected the root fresh and dry weight/ plant. Sandy soil gave the higher values of root fresh and dry weight/ plant than clay soil, while clay loam gave the greatest values than other soil types in both seasons. Either sandy and sandy clay loam soils or sandy loam and clay loam soils were statistically equal in producing significant plant herb fresh and dry weight/plant of marigold plants in the two seasons in (Table, 2). These finding are in harmony with those obtained by Mahros (2000) on Aster novi -belgii L., Moustafa (2004) on Dalbergia sissoo and Parkinsonia aculeate and Soliman (2005) on Khaya segenalensis seedlings found that sandy soil and mixed soils promoted root

Fayoum J. Agric. Res. \& Dev., Vol.22, No.2, July, 2008 
system growth over the clay soil, and this may be due to that sandy or mixed soil forces the roots of both trees to penetrate faster and longer searching for water and nutrient's.

Data in Table (2) noticed that root fresh and dry weight/ plant significantly increased by increasing organic soaker rates in the both seasons. The high rate of poultry manure soaker fertilizer gave the greatest values of weight of fresh and dry root/ plants in the two seasons. These results are in agreement with the findings reported by Abd El-Kader (1999) on fennel, anise plants and Matter and Somida (2006) on Ocimum basilicum L. plants.

The interaction between the soil texture grades and organic soaker significantly increased root fresh and dry weight/plant. Clay soil which fertilized with organic soaker gave the lowest values of root fresh and dry weight/ plant. While, clay loam which fertilized with organic soaker gave the highest values of root fresh and dry weight/ plant. No significantly difference were noticed between the sandy and sandy clay loam soils, while sandy loam and clay loam which fertilized with organic soaker in producing significant values of root fresh and dry weight/ plant in the two seasons. So, the highest values were obtained when marigold plants grown on clay loam and fertilized with poultry manure soaker at rate $1.5 \mathrm{~kg} / 20 \mathrm{~L}$. water, as indicted in Table (2).

4- Number of flowers and flowers fresh and dry weight/plant (gm):

Data in Table (3) indicated that all used soil texture grades significantly affected the number of flowers and flowers fresh and dry weight/plant. Sandy soil gave the lowest values than other soil types. Both sandy and clay were statistically equal in producing significant number of flowers and flowers fresh and dry weight/plant of marigold plant in the two seasons. Clay loam gave the highest values than other soil types in the two seasons. Both Sandy loam and clay loam were statistically equal in producing significant plant herb fresh and dry weight/ plant in the two seasons. El-Shoura and Hosni (1996) on Sterlitzia reginae, Mahros (1999) on tuberose plants

The number of flowers and flowers fresh and dry weight/plant significantly increased by increasing organic soaker rates in the two growing seasons. The rate of $1.5 \mathrm{~kg} / 20 \mathrm{~L}$., from poultry manure soaker fertilizer surpassed the rates of 0.5 and 1.0 and $\mathrm{kg} / 20 \mathrm{~L}$., in producing significant number of flowers and flowers fresh and dry weight/plant in the two seasons as indicated (Table 3). So the highest values were obtained when marigold plants received poultry manure at a rate of $1.5 \mathrm{~kg}$ soaked in 20 Liter of water. These results are in agreement with the findings reported by Matter and Mohamed (2001) on Calendula officinalis L. Abd EL-Raouf (2001) ; El-Gendy et al. (2001) and El-Yazal et al.(2005) Matter and Somida (2006) on Ocimum basilicum L.

Data in table (3) shows that the interaction between the soil texture grades and organic soaker significantly increased number of flowers and flowers fresh and dry weight/plant. Sandy soil fertilized with organic soaker gave the lowest values of number of flowers and flowers fresh and dry weight/plant. While, clay loam which fertilized with organic soaker gave the highest values of number of flowers and flowers fresh and dry weight/plant. No significantly difference were noticed between the sandy and clay soils, while sandy loam and clay loam which fertilized with organic soaker in producing significant number of flowers and flowers fresh and dry weight/plant in the two seasons. So, the highest values were obtained when marigold plants were grown on clay loam and fertilized with poultry manure soaker at a rate of $1.5 \mathrm{~kg} / 20 \mathrm{~L}$., water.

Fayoum J. Agric. Res. \& Dev., Vol.22, No.2, July, 2008 
EFFECT OF DIFFERNT SOIL TEXTURAL GRADES AND SOAKER ... 66

Table 2

Fayoum J. Agric. Res. \& Dev., Vol.22, No.2, July, 2008 
Table 3

Fayoum J. Agric. Res. \& Dev., Vol.22, No.2, July, 2008 


\section{EFFECT OF DIFFERNT SOIL TEXTURAL GRADES AND SOAKER ... 68}

\section{6- Flowering percentage:}

Results in Table (3) showed that soil texture grades significant affected the flowering percentage in both studied seasons. Clay soil gave the lowest flowering percentage than other soil types. It is noteworthy to mention that, the sandy and clay soils were equally effective in raising fresh flowering percentage per plant. However, Clay loam gave the highest flowering percentage than other soil types in the two seasons. Both sandy loam and clay loam were statistically equal in producing significant flowering percentage in the two seasons on marigold plants. El-Shoura and Hosni (1996) on Sterlitzia reginae plants

Data in Table (3) showed that, poultry manure soaker fertilizer treatments significantly increased flowering percentage per plant in the two growing seasons in comparison with that of the low rate, especially at the $1.5 \mathrm{~kg} / 20 \mathrm{~L}$. which gave the best result for flowers percentage reached 90.08 and 91.29 for sandy soil; 88.74 and 89.88 for clay soil; 93.15 and 94.28 for sand clay loam ; 93.39 and 94.50 for sandy loam and 97.23 and 98 . \% for clay loam respectively in the two seasons. Therefore, it advised, form the economical point of view, to supply marigold plants with $1.5 \mathrm{~kg} / 20 \mathrm{~L}$ of poultry manure soaker in water for 24 hour. The combination between soil texture grades and poultry manure soaker fertilizer was found to have synergistic effect in producing flowering percentage per plant. The highest value of the flowering percentage was obtained when marigold grown on clay loam and fertilized with poultry manure soaker at a rate of $1.5 \mathrm{~kg} / 20 \mathrm{~L}$. Also, from the data recorded in Table (3) it's clear that no significant effect between the sandy and clay soils or sandy loam and clay loam which fertilized with poultry manure soaker in producing flowering percentage.

In order to discuss the promoting effects of soil texture grades by mixing soil over sandy and clay in this study for improving vegetative growth traits and chemical composition of Tagetes patula L., which have good structure and congaing appreciable quantities of silt and clay (Table1), as well as better aerification than the clay soil, the roots are longer and that leads to more support with water and nutrients, and in turn reflected positively in the vegetative growth traits. Clay and mixed soils enhanced vegetative growth traits over sand soil could be attributed to the fact that soil has much more nutrition with different essential macro and microelements as shown in Table (1), in addition to its unique physical, chemical and biological properties i.e. higher water holding capacity, better cation exchange capability, more organic matter nutrients availability and uptake and more beneficial microbial organisms (Kramar, 1969 and Soliman, 2005). Sand soil is poor in physical, chemical and nutritional properties i.e. low water holding capacity, cation exchange capacity, lower organic matter, low nutrients availability and uptake and more beneficial microbial organisms. To improve the physical, chemical and nutritional properties of sandy soil it must be incorporating with clay or organic manures into this soil.

Organic manure soaker water that contained macro and microelements as shown in Table (1) on different vegetative growth characters, as well as other yield component parameters and oil production of Tagetes patula L., plants. It is necessary to refer to the physiological roles of the mineral nutrients such as nitrogen and potassium in plant growth and development. Nitrogen is a constituent of most organic compounds such as amino acids, many enzymes and energy transfer materials such as chlorophyll, ADP and ATP. Growing

Fayoum J. Agric. Res. \& Dev., Vol.22, No.2, July, 2008 
plants must have nitrogen to form new cells and the rate of growth is proportional to the rate at which nitrogen is supplied.. It aids in the uptake of other nutrients and their movement within the plant. Beringer (1978) and Mengel and Kirkby (1987) reported that, the role of K in metabolism, growth and yield formation can be characterized by two major function: as an activator of 60 enzymes and as $\mathrm{K}^{-}$ions are very mobile within the plant as well as within a cell are transported through biological membranes with high rate and specificity. More than 60 enzymes are known to require $\mathrm{K}^{+}$as an activator. They participate directly or indirectly in much important physiological process carried on simultaneously within plant cells, tissues and organs differentiation. Plant supplement with these macronutrients in soil of fertilizers is necessary because the soil is usually in deficient of them or they are not readily available for plants.

\section{B-Chemical composition}

1 - Volatile oil percentage and yield $(\mathrm{ml})$ per flower of plant:

Soil texture grades significantly affected the volatile oil percentage/flower of plant and as well as oil yield/flower of plant. Sandy soil gave the lowest volatile oil percentage and yield than other soil types. No significantly difference was observed between the soil types in producing volatile oil percentage/flower of plants. Clay loam gave the highest volatile oil percentage and yield/ flower of plant than other soil types in the two seasons. Both Sandy loam and clay loam were statistically equal in producing significant volatile oil percentage and yield/flower of plant in the two seasons as indicated in Table (4). Similar results were reported by Youssef, et al., (1998) on Ocimum basilicum L., plants.

Data in Table (4) revealed that organic manure soaker fertilization levels significantly increased volatile oil percentage and yield/flower of plant of on marigold plants, in the both seasons compared to the low level. Poultry manure soaker at a rate of $1.5 \mathrm{~kg} / 20 \mathrm{~L}$ surpassed the low rate of $0.5 \mathrm{~kg} / 20 \mathrm{~L}$. and medium rate of $1.0 \mathrm{~kg} / 20 \mathrm{~L}$. in rising volatile oil percentage and yield/flower of plant in both seasons. by Abd EL-Raouf (2001); El-Gendy $\boldsymbol{e} t$ al., (2001) and El-Yazal, et al., (2005) and Matter and Somida (2006) on Ocimum basilicum L.

The combination between soil textures grades such and poultry manure soaker fertilizer was found to have synergistic effect in producing volatile oil percentage and yield/flower plant. The highest values of the volatile oil percentage and yield/flower of plant were obtained when marigold was grown on clay loam and fertilized with poultry manure soaker at a rate of $1.5 \mathrm{~kg} / 20 \mathrm{~L}$. From the data recorded in Table (4), it's clear that no significant effect between the soil types fertilized with organic soaker fertilizer in producing volatile oil percentage. But sandy and clay soils or sandy loam and clay loam which fertilized with poultry manure soaker were statistically equal in producing oil yield in both seasons.

\section{2 - Caroteniods content ( $\mathrm{mg} / \mathrm{g}$ fresh weight flowers):}

Data in Table (4) showed that use of soil texture grades significantly affected caroteniods contents of marigold plants. Sandy soil gave the lowest caroteniods content than other soil types. It is noteworthy to mention that, the sandy and clay soils were equally effective in raising caroteniods content. Clay loam gave the highest caroteniods content than other soil types in the two seasons. Both sandy loam and clay loam were statistically equal in producing significant caroteniods content of marigold plants in the two seasons. This

Fayoum J. Agric. Res. \& Dev., Vol.22, No.2, July, 2008 
EFFECT OF DIFFERNT SOIL TEXTURAL GRADES AND SOAKER ... 70

result is in harmony with that obtained by Saleh (2000) on Ficus benjamina starlight plants.

Data in Table (4) showed that, poultry manure soaker fertilizer caused a significant increase in caroteniods content in the two growing seasons especially at the $1.5 \mathrm{~kg} / 20 \mathrm{~L}$., in comparison with that of the low rate especially at the $0.5 \mathrm{~kg} / 20 \mathrm{~L}$., which gave the best value of caroteniods content, which .reached 9.25 and 9.75 for sandy soil; 10.11 and 10.61 for clay soil ; 11.55 and 12.05 for sand clay loam; 12.25 and 12.75 for sandy loam; 13.56and $14.06 \%$ for clay loam respectively in the two seasons. Therefore, it advised, form the economical point of view, to supply marigold plants with $1.5 \mathrm{~kg} / 20 \mathrm{~L}$ of poultry manure soaker in water for 24 hour. Similar results were reported by Matter and Mohamed (2001) on Calendula officinalis L., Sakr (2001) on Mentha piperta L. and Mohamed (2006) on roselle.

In addition, data in Table (4) revealed that caroteniods contents were significantly affected by the interaction between soil texture grades and organic manure soaker. The highest amount of caroteniods content obtained from sowing in clay loam (clay+ sandy at rate $2: 1 \%$ ) and treated with poultry manure soaker at rate $1.5 \mathrm{~kg} / 20 \mathrm{~L}$ in both seasons. From the data recorded in Table (4), it's clear that no significant effect between the sandy and clay soils or sandy loam (clay + sandy at rate 1:2\%) and clay loam ( clay + sandy at rate 2:1 $\%)$ which fertilized with poultry manure soaker in producing caroteniods contents.

3- Nutrient contents (Nitrogen, phosphorus and potassium percentage):

Soil texture grades significantly affected nutrient contents (N, P and K) of marigold plants. Sandy soil gave the lowest nutrient contents (N, P and K) than other soil types. It is noteworthy to mention that, clay loam (clay + sandy at rate $2: 1 \%)$ gave the highest nutrient contents $(\mathrm{N}, \mathrm{P}$ and $\mathrm{K})$ than other soil types in the two seasons. Both sandy loam (clay + sandy at rate 1:2 \%) and clay loam (clay+ sandy at rate 2:1\%) were statistically equal in producing significant nutrient contents (N, P and $\mathrm{K}$ ) of marigold plants in the two seasons as indicate in Table (4). These findings are in agreement with those obtained by El-Shoura and Hosni (1996) on Sterlitzia reginae plants, Saleh (2000) on Ficus benjamina starlight plants.

Poultry manure soaker fertilizer treatments also caused significantly increased nutrient contents $(\mathrm{N}, \mathrm{P}$ and $\mathrm{K})$ during the two growing seasons as compared to that of the low rate of $0.5 \mathrm{~kg} / 20 \mathrm{~L}$. especially at the $1.5 \mathrm{~kg} / 20 \mathrm{~L}$. which gave the greatest values of nutrient contents $(\mathrm{N}, \mathrm{P}$ and $\mathrm{K})$ in the two seasons. Therefore, it advised, form the economical point of view, to supply marigold plants with $1.5 \mathrm{~kg} / 20 \mathrm{~L}$, of poultry manure soaker in water for 24 hour. Similar results were reported by Mohamed and Matter (2001) on Tagetes minuta L., Matter and Mohamed (2001) Calendula officinalis L, ElYazal et al. (2005) on Ocimum basilicum L and Mohamed (2006) on roselle plants.

Data in Table (4) also revealed that nutrient contents (N, P and $\mathrm{K}$ ) significantly affected by the interaction between soil texture grades and organic manure soaker. The highest nutrient contents $(\mathrm{N}, \mathrm{P}$ and $\mathrm{K})$ obtained from sowing on clay loam (clay+ sandy at rate $2: 1 \%$ ) and treated with poultry manure soaker at rate $1.5 \mathrm{~kg} / 20 \mathrm{~L}$ in both seasons. Also from the data recorded in Table (4) it's clear that no significant effect between the sandy loam (clay + sandy at rate $1: 2 \%$ ) and clay loam ( clay + sandy at rate $2: 1 \%$ ) which fertilized with poultry manure soaker in producing nutrient contents ( $\mathrm{N}, \mathrm{P}$ and $\mathrm{K})$.

Fayoum J. Agric. Res. \& Dev., Vol.22, No.2, July, 2008 
Table 4

Fayoum J. Agric. Res. \& Dev., Vol.22, No.2, July, 2008 
EFFECT OF DIFFERNT SOIL TEXTURAL GRADES AND SOAKER ... 72 4 - Total carbohydrates content (mg/g D.W.) :

Data in Table (4) show that total carbohydrates content significant affected by soil texture grades. Sandy soil gave the lowest total carbohydrates content than other soil types. The sandy and clay soils were equally effective in raising total carbohydrates content. However, clay loam (clay + sandy at rate $2: 1 \%)$ gave the highest total carbohydrates content than other soil types in the two seasons. Both sandy and clay as well as Sandy loam ( clay + sandy at rate $1: 2 \%$ ) and clay loam (clay+ sandy at rate $2: 1 \%$ ) were statistically equal in producing significant total carbohydrates content in the two seasons on marigold plants. This results are in agreement with those obtained by Youssef, et al., (1998) on Ocimum basilicum L., plants.

Total carbohydrate content was gradual and parallel increased to the fertilized by poultry manure soaker. Poultry manure soaker at a rate of $1.5 \mathrm{~kg}$ /20L surpassed the low rate $(0.5 \mathrm{~kg} / 20 \mathrm{~L}$. $)$ and medium rate $(1.0 \mathrm{~kg} / 20 \mathrm{~L}$. $)$ in raising total carbohydrates in both seasons, as shown in Table (4).by Mohamed and Matter (2001) on Tagetes minuta L., Matter and Mohamed (2001) Calendula officinalis L, El-Yazal et al. (2005) on Ocimum basilicum L and Mohamed (2006) on roselle plants.

Data in Table (4) revealed that total carbohydrates content was significantly affected by the interaction between soil texture grades and organic manure soaker. The highest amount of total carbohydrates content obtained from sowing in clay loam (clay+ sandy at rate $2: 1 \%$ ) and treated with poultry manure soaker at a rate of $1.5 \mathrm{~kg} / 20 \mathrm{~L}$ in both seasons. From the data recorded in Table (4), it is clear that no significant effect between the sandy and clay soils as well as sandy loam (clay + sandy at rate 1:2 \%) and clay loam (clay + sandy at rate $2: 1 \%$ ) which fertilized with poultry manure soaker in producing total carbohydrates content.

In conclusion, it could be recommended from the healthy and economical aspects that use sandy loam soil (clay + sandy at rate $1: 2 \%$ ) or clay loam soil (clay + sandy at rate 2:1\%) fertilized with soaker water of poultry manure at rate of $1.5 \mathrm{~kg} / 20 \mathrm{~L}$. to was more effective to produce Tagetes patula L., plants having the tremendous growth rates and high volatile or oil content as well as to alleviate the hazard our effect of soil pollution as a result of using chemical fertilizers in agricultural purposes.

\section{REFERENCES}

Abd-El-Kader, A.A. (1999): Nitrogen nutrition of fennel (Foeniculum vulgaris Mill) and anise (Pimpinella anisum L.) and their effects on growth and essential oil contents. M.Sc. Thesis Faci. Agric., Assiut Univ., Egypt.

Abd El-Raouf; R.M.S. (2001): Production of sweet basil (Ocimum basilicum L.) in the new reclaimed lands under different levels of biofertilizers and plant density. M.Sc. Thesis, Fac. Agric., Ain Shams Univ.

Abdou , M.A.; Baderan, F.S. ; Sharaf El-deen, M. N. ; Aly, M.K. and Mohamed, S.H. (2003): Evaluation of six woody tree seedling growen in different soil types and North Coast environmental condation $1^{\text {st }}$ Egyptian-Syrian Conference For Agriculture and Food in the Arabian Nation Minia Univ., Egypt, December, 8-11.

Alam, A.U.; Couch, JR. and Creeger, C.R. (1968): The Caroteniods of marigold, Tagetes erecta. Canada. J. Bot. 46, 1539.

A.O.A.C. (1995): Official Methods of Analysis of the Association Official Agricultural chemist, Franklin Station. Washington, D.C.B.

Fayoum J. Agric. Res. \& Dev., Vol.22, No.2, July, 2008 
Beringer, H. (1978): Functions of potassium in plant metabolism with particular reference of yield pp. 185-202. In G. S. Sekhon (ed.) Potassium in soils and crop. New Delhi. India: Potash Res. Institute of India; (c.f. Fertilizer Abst. ( 2), 1981).

Black, C. A., Evan, D. D., Ensmingare, L. E., White, I.J. and Chark, F. E.(1965): Methods of Soil Analysis. Parts1 \& 2. Am. Soc. Agron., Madison. Wisconsin. USA.

British Pharmacopoeia (1983):The pharmaceutical press 17. Bloomsbury, square London W.C.I.

Chan, G.F.O.; Tower, G.H.N. and Mitohell, J.C. (1975): Ultraviolet- mediated antibiotic activity of thiophene compound of Tagetes. Phytochemstry, 14 (10): 2295.

Chapman H.D. and Paratt, P.F.(1978): Method of Analysis for Soil, Plant and Waters. Univ. California, Div. Agric. Sci., 17: 150.

Darwish, A.A.A.(1992): Laboratory studies of toxicity and effect of some plant extracts as stored product protections. Egypt. J. Appl . Sci. ,7(12): 138.

El-Gendy, S.A.; Hosni, A. M.; Ahmed, S.S. and Saber, R.M. (2001): Sweet basil (Ocimum basilicum L.) productivity under different organic fertilization and inter-plant spacing levels in a newly reclaimed land in Egypt Ann. Agric. Sci., Ain Shams Univ., 46 (1): 319-338.

El-Sallami, I. H. (2002): Seedling response of some ornamental to some soil media and bio fertilization treatments. Annals of Agric. Sci., Moshtoher, 40 (4): 2233-2245.

El-Shoura, H.A.S. and Hosni, A.M. (1996): Growing Sterlitzia reginae Ait in improved sandy growing media under different levels of fertilization. Annals Agric. Sci. , Ain Shams Univ., 41(2):973-991.

El-Ghadban, E.A.A.E. (1998): Effect of some organic and chemical composition of spearmint and marjoram plants. Ph. D. Thesis, Fac. Agric., Cairo Univ., Egypt.

El-Yazal, M.A.; El-Yazal, Sawsan, A. and Somida. E.G. (2005): Effect of soil application of poultry manure, soil and foliar spray of potassium sources on growth and chemical constituents of Ocimum basilicum L., sweet basil. Egypt J. of Appl. Sci., 20 (12B): 485- 508.

Gomes, K.A. and Gomes, A.A. (1983): Statistical Analysis Procedure of Agricultural Research. John Wiley and Sons, New York, pp. 25-30.

Herbert, D.; Phipps, P.J. and Strange, R.A. (1971): Determination of Total Carbohydrate, Methods in Microbiology, 5B, Academic Press London, pp 209-344.

Kramar, P.J. (1969): The Role of Water in Plant Physiology. Adv. In Agric., Willy and Sons, N.Y. USU.

Kapelev, I.G.(1971): Marigolds as essential oil plants. Rastitel nque Resursy ,7 (4) :571.

Kapelev, I.G.(1973): Introduction of aromatic plants. Byulleten. Gosuclarst vnogo NIhits Kogo Botanicks Kogo Sada, 2 (21): 16.

Kapelev, I.G.(1975): Introduction of marigolds as essential oil plants. Trudy popvik ladoni Genetike Selectsii ,54 (2): 231.

Kumari, R. ; Verma, K.K.; Dhindsa, K.S. and Bhatti, D.S. (1987): Screening aerial parts of Datura, Ipomoea, Tagetes and Iawsonia for their nematicidal activity on Meloidogyne Javanica. Agric. Sci. Digest., 7(4): 213

Fayoum J. Agric. Res. \& Dev., Vol.22, No.2, July, 2008 
EFFECT OF DIFFERNT SOIL TEXTURAL GRADES AND SOAKER ... 74

Mahros O.M.(1999): Response of Polianthes tuberosa L., to different growing media, planting depth and size of bulbs . Assiut J. of Agric. Sci., 57 (3):133-154.

Mahros, O.M.(2000): Effect of planting media and NPK fertilization on growing and chemical constituents of Aster nova-belgh L.,. Assiut J. of Agric. Sci.,.31(2):1-19.

Matter, F.M.A. and Mohamed, S.A. (2001): Botanical studies on Calendula officinalis L. plants as affected by organic and inorganic fertilizers under newly reclaimed soil condition. Fayoum J. Agric. Res. Dev., 15(2): 50-65.

Matter, F.M.A. and Somida, E.G. (2006): Effect of propagation methods and organic fertilization on growth and chemical constituents of Ocimum basilicum L., "sweet basil". Fayoum J. Agric., Res. \& Dev., 20 (2): 66-83.

Mengel, K. and Kirkby, E.A. (1987): Principles of Plant Nutrition. International Potash Institute. Switzerland, 4th edition

Michel, K.A.; Gilles, J.K.; Hamilton, P.A. and Freed, S. (1956): Colorimetric method for determination of sugars and relate substances .Analytical Chemistry, 28(3).

Miller, P.M. (1971) : Morvis Arborctum Bulletin. 22(4):78.

Mohamed, S. E. A (2006): A comparison between the effect of different sources of organic and mineral fertilizers on growth, anatomical structure, yield and chemical composition of roselle (Hibiscus sabdariffia L.,) plants. The Second Conference on Farm Integrated Pest Management 1618 Jan .2006 pp: 99-111 in Fac. Agric., Fayoum Univ.

Mohamed, S.A. and Matter, F.M.A. (2001): Effect of ammonium nitrate and organic fertilizers on growth, volatile oil yield and chemical constituents of marigold (Tagetes minuta L.) plant. Fayoum J. Agric., Res. Dev., 15(1): 95-107.

Moustafa, H.I.B. (2004): Studies on some factors affecting seed germination and seedling growth of some trees. M.Sc. Thesis, Fac. Agric., Minia Univ. Egypt.

Page, A.I.; Miller, R.H. and Keency, D.R. (eds) (1982): Methods of soil Analysis Part II. Chemical and Microbiological Methods. $2^{\text {nd }}$ ed Am. Soc. Agron., Madison, Wisconsin U.S.A

Sakr, W.R.A.S. (2001): Effect of some organic and inorganic fertilizers on Mentha piperta. M.Sc. Thesis, Fac. Agric., Cairo Univ., Egypt.

Saleh S.I.I. (2000): Effect of different planting media on growth and chemical composition of Ficus benjamina 'starlight' plants grown under two locations" outdoor and plastic house" condition. Egypt. J. Hort., 27 (4): 543-568.

Soliman, Y.M.Y. (2005): Effect of bio and chemical fertilization on the growth and chemical composition of some woody trees seedlings growth in different soil types. M.Sc. Thesis, Fac. Agric., Minia Univ. Egypt.

Somida, E.G. (2002): Effect of organic manure, nitrogen and potassium fertilization on growth, flowering and chemical constituents of marigold plants (Tagetes minuta L.,) Ph.D. Thesis, Fac. Agric. , Fayuom, Cairo Univ., Egypt.

Welburn, A.R. and Lichtenthaler, H. (1984): Formula and program to determine total caroteniods and chlorophyll $a$ and $b$ of leaf extracts different solvents In Advances in photosynthesis Research (Sybesma C.Ed.) Vol., II pp. 9- 12.Mortinus Njihoff Dr.W. Junk publishers, the Hague.

Fayoum J. Agric. Res. \& Dev., Vol.22, No.2, July, 2008 
Youssef, A.A.; Iman Talaat, M. and Omer, E.A. (1998): physiological response of basil green ruffes (Ocimum basilicum L.,) to nitrogen fertilization in different soil types. Egypt. J. Hort., 25 (2) : 253-269.

$$
\begin{aligned}
& \text { تأثير رتب مختلفة من قوام التربة والمنقوع المائى للمخصب العضوي على النمو الخضري ،التزهير } \\
& \text { والمكونات الكيماوية لنباتات القطيفة القية }
\end{aligned}
$$

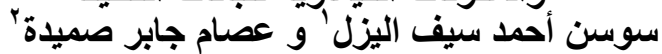

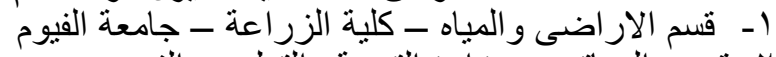

$$
\begin{aligned}
& \text { r- قسم البساتين - وزارة التربية والتعليم - الفيوم - مصر الفرم }
\end{aligned}
$$

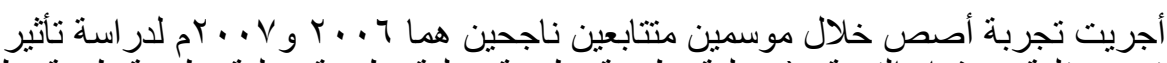

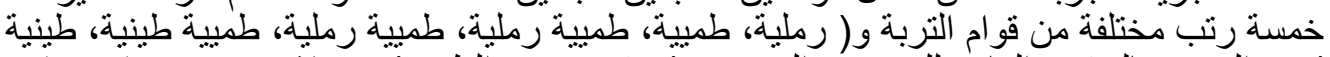

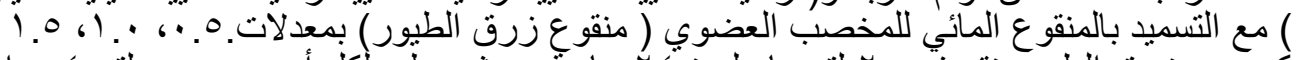

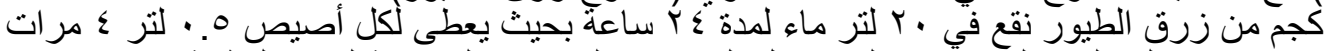

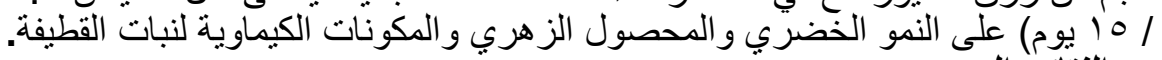
وتثثير النتائج إلى إلى

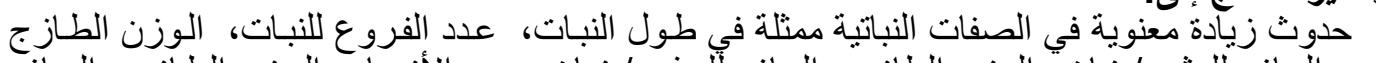

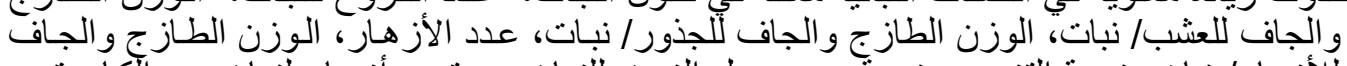

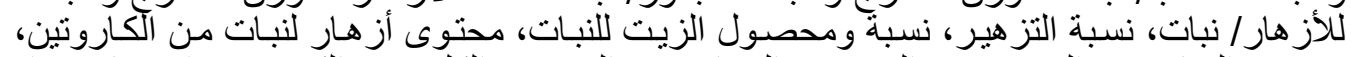

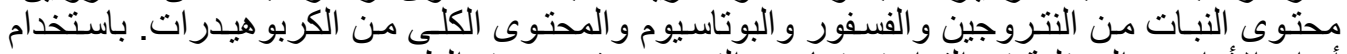

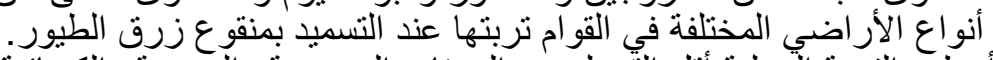

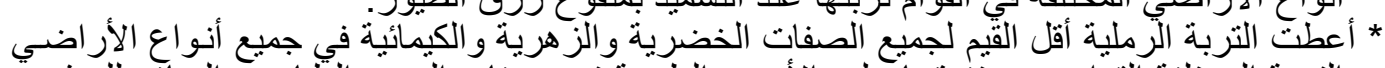

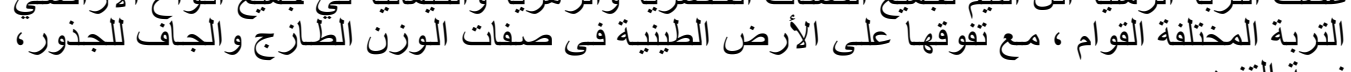

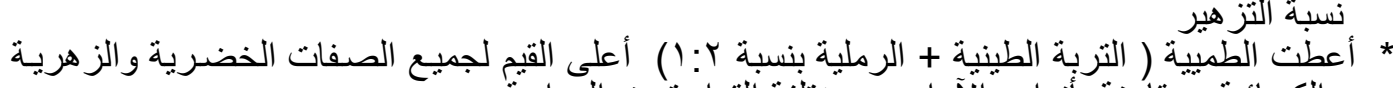

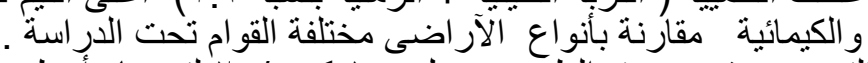

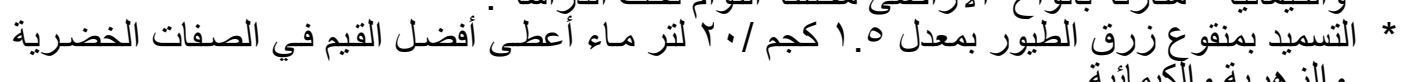

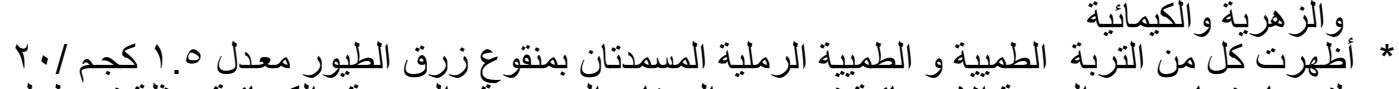

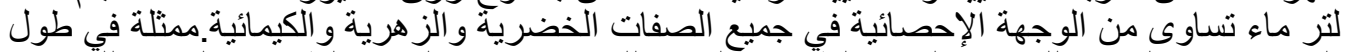

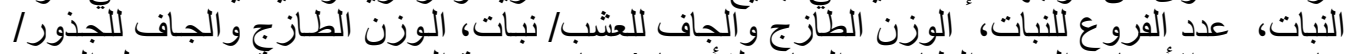

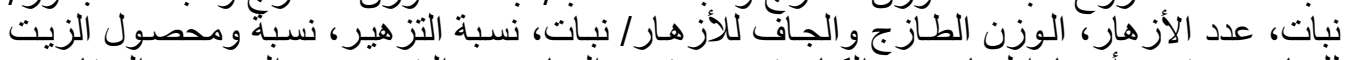

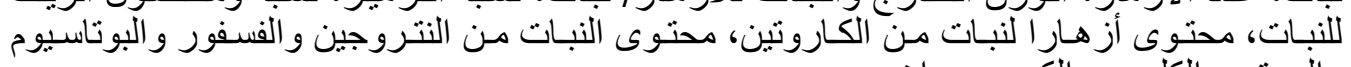
و المحتوى الكلى من الكربو هيدرات.

Fayoum J. Agric. Res. \& Dev., Vol.22, No.2, July, 2008 